\title{
Oral Tumor Revealing Primary Plasma-cell Leukemia
}

\author{
Maryame Ahnach@, Houda Youssefi®, Mounia Bendari® \\ Department of Hematology, Cheikh Khalifa International University Hospital, Mohammed VI University of Health Sciences, Casablanca, Morocco
}

A 37-year-old woman was admitted to the Hematology Department with a 2-month history of a growth inside the oral cavity in the upper jaw and weakness. Physical examination revealed a voluminous mass involving the left side of the maxillary gingiva (Figure A). The maxillofacial computerized tomography scan confirmed the presence of a solid tissue mass at the left upper maxilla. The histopathological diagnosis obtained from the oral biopsy showed a large plasmacytoid infiltration with dystrophic plasma cells. The immunohistochemistry was positive for CD138, CD38, and IgG lambda antibodies, with negative expression of CD56 (Figure B). The laboratory findings revealed a low hemoglobin level of $75 \mathrm{~g} / \mathrm{L}$, a renal impairment with creatinine level of $23 \mathrm{mg} / \mathrm{L}$, and hypercalcemia of $191 \mathrm{mg} / \mathrm{L}$. Serum protein electrophoresis confirmed a monoclonal peak of IgG lambda, with lambda free light chain level at $14206 \mathrm{mg} / \mathrm{L}$. The diagnosis of primary plasma cell leukemia (pPCL) was subsequently confirmed by peripheral blood smear (25\% of plasma cells) and bone marrow aspiration $(50 \%$ of plasma cell infiltration) (Figure $\mathrm{C}$ ) with a normal karyotype. The most important differential diagnosis is plasmacytoma/multiple myeloma; however, myeloma with rare extramedullary involvement would not fulfil the diagnostic criteria of $20 \%$ or more clonal plasma cells on the peripheral blood film.

The patient received 4 cycles of VTD protocol (bortezomib, thalidomide, and dexamethasone) followed by autologous stem cell transplant. At the 6-month follow-up after transplant, the patient relapsed with multiple extramedullary lesions under ineffective rescue therapy (lenalidomide, cyclophosphamide, and dexamethasone).
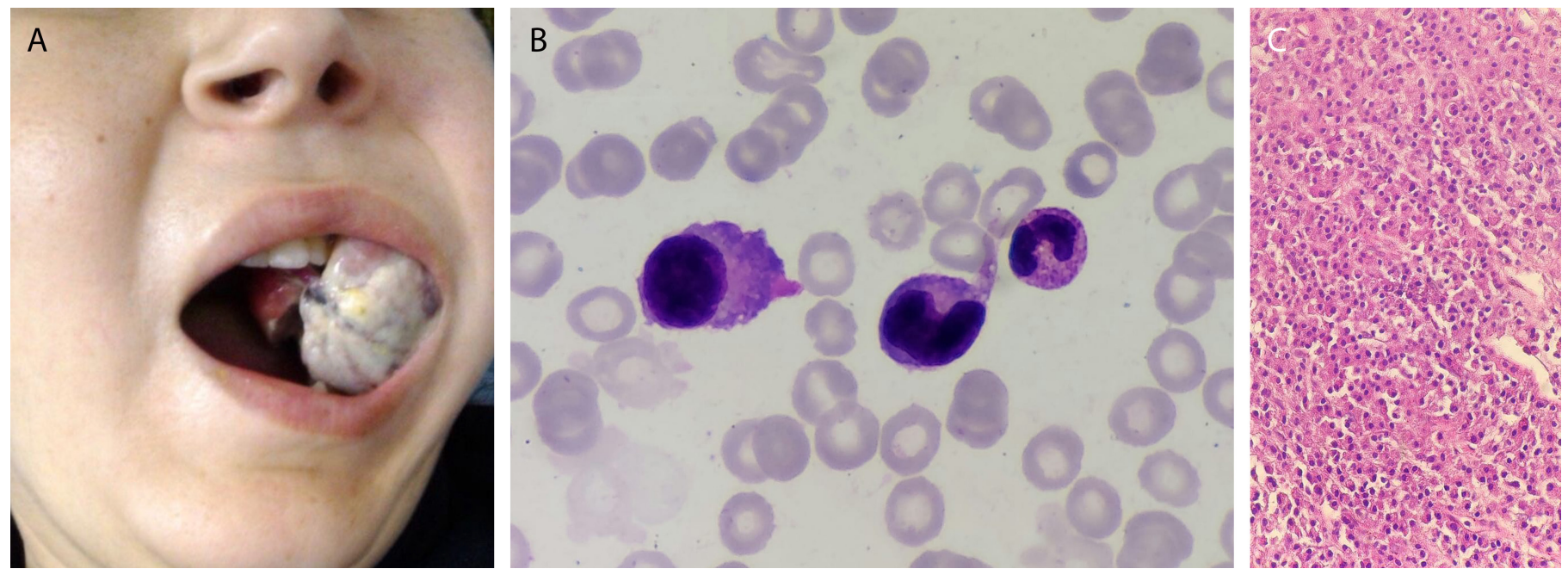

FIG. 1. A-C. (A) Oral mass lesion in the left gingiva emerging from the upper maxilla. (B) Dystrophic plasma cell infiltration in bone marrow aspiration (MGGX400). (C) Plasma cell infiltration in biopsy of oral lesion (HEx40).

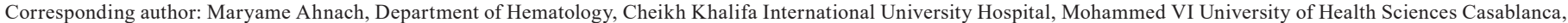
Morocco

e-mail: mahnach@um6ss.ma

Received: August 8, 2021 Accepted: October 8, 2021 •DOI: 10.5152/balkanmedj.2021.21734

Available at www.balkanmedicaljournal.org

ORCID iDs of the authors: M.A. 0000-0002-1832-7672; H.Y. 0000-0003-2837-0719; M.B. 0000-0001-8414-2855.

Cite this article as:

Ahnach M, Youssefi H, Bendari M. Oral tumor revealing primary plasma-cell leukemia. Balkan Med J. 2021; 38(6):392-393.

Copyright@Author(s) - Available online at http://balkanmedicaljournal.org/ 
Primary plasma cell leukemia remains the most aggressive form of plasma cell dyscrasias with a dismal prognosis and an overall median survival of 7 months. pPCL is mostly diagnosed in younger patients with frequent extra medullary involvement compared to multiple myeloma. Clinicians have to be alert to atypical oral lesions in pPCL, this initial clinical presentation remains exceptional. ${ }^{1}$ Management should include early innovative treatment approaches, incorporating various modalities to improve outcome with early aggressive chemotherapy and allogenic stem cell transplant. ${ }^{2,3}$

Patient Consent for Publication: The patient's consent was taken verbally with the patient's parents because she recently died.
Author Contributions: Concept - M.A., H.Y; Design - M.A., H.Y.; Data Collection and/or Processing - M.A., H.Y.; Analysis and/or Interpretation - M.A., H.Y.; Literature Review - M.A., H.Y.; Writing - M.A., H.Y., M.B.

Conflict of Interest: The authors have no conflicts of interest to declare.

\section{REFERENCES}

1. Wong P, Kashtwari D, Nair MK. Radiographic features of plasma cell leukemia in the maxilla: a case report. Imaging Sci Dent. 2016;46(4):273-278. [CrossRef]

2. van de Donk NW, Lokhorst HM, Anderson KC, Richardson PG. How I treat plasma cell leukemia. Blood. 2012;120(12):2376-2389. [CrossRef]

3. Gundesen MT, Lund T, Moeller HEH, Abildgaard N. Plasma cell leukemia: definition, presentation, and treatment. Curr Oncol Rep. 2019;21(1):8. [CrossRef] 